\title{
Europe opens high-tech stockmarket...
}

Oxford. Millionaire European scientists may become commonplace following the launch next month of a pan-European stock exchange for high-growth companies.

A similar exchange in the United States, NASDAQ, nurtured the development of three of America's leading high technology giants, Microsoft, Intel and the biopharmaceutical blockbuster Amgen. Europe hopes to repeat the US success.

The high-tech focused pan-European stock exchange has been dubbed EASDAQ - the European Association of Securities Dealers Automated Quotation system. Its opening is expected to have three major impacts on Europe's technology base.

First, it should slow the flight of hightech companies to the United States. Second, it should make it easier for scientists to get seed funding for ideas they have for new companies. And third, scientists could find themselves being turned into millionaires if the ideas underpinning their companies capture the investment community's imagination.

The new exchange is looking to attract young fast-growing companies in areas such as advanced materials, biotechnology, environmental technology, Internet service providers, medical technology and software houses. A number of companies have been lined up for the opening day of the new exchange, including the Belgian biotechnology diagnostics company Innogenetics.

European financiers are offering highgrowth companies - many of them hightech based - an opportunity to raise funds by trading their shares publicly. Raising funds to commercialize high-tech applications, particularly in biotechnology, has until now been a difficult operation in Europe. European investors have been notoriously conservative when investing in new businesses, considering them to be too risky. Investors tend to like to know when they will see a high return for their initial gamble.

One of the best routes for making profits from an investment is to sell the stake when the company starts trading its shares to the public through one of the stock exchanges. However, the rules to list shares on these exchanges make it difficult for small and new companies to be able to use that route.

It is believed that this lack of funding - a so-called equity gap - has held back the development of entrepreneurial high-tech firms in Europe. By creating a well regulated quality exchange without cowboy companies the EASDAQ founders believe they can tip the high risk/high return balance in favour of the investor. This shift in the balance is then expected to catalyse greater interest in similar companies and ideas.

Mike Ward

\section{... as biotech deal sets record}

Oxford. In the largest deal so far involving an entrepreneurial European bioscience company, AgrEvo, a German pesticides producer, has bid US\$550 million to acquire 75 per cent of Plant Genetics Systems International (PGS), the BelgianDutch plant biotechnology specialist. The final bill, however, could come to more than $\$ 730$ million, as the German multinational plans to acquire the whole company.

PGS has always been at the cutting edge of agricultural biotechnology and possesses a broad portfolio of patents covering important agronomic traits and enabling technologies for genetically modified crops. One of the company's main achievements has been the modification of crops so that they can tolerate the presence of Basta, a broadspectrum weedkiller developed by AgrEvo that allows farmers to control all weeds in one shot without harming the crop.

It has been estimated that the market for genetically modified crops could reach \$6 billion worldwide by 2005 . Although AgrEvo's acquisition of PGS is not that surprising, the price looks very large. Last year, Monsanto acquired a 49.9 per cent

\section{Environment game gives taste of treaties}

Boston. Scientists at the Massachusetts Institute of Technology (MIT) have invented a game - the Chlorine Game that gives students a taste of negotiating an international environment treaty, and is said to point to a better approach to drawing up diplomatic protocols.

The task of the twelve players, representing eight countries and four non-governmental organizations, is to draft a treaty governing the worldwide use of organochlorines. This class of chemicals includes chlorofluorocarbons (CFCs), polychlorinated biphenyls (PCBs) and the oestrogenmimicking compounds that some blame for declining sperm counts in men.

The game was invented by Lawrence Susskind and his colleagues in MIT's Department of Urban Studies and Planning. Susskind wrote Environmental Diplomacy: Negotiating More Effective Agreements, and has advised governments on environmental treaty negotiations.

Students at MIT and Harvard Law School play the game. Several United Nations conferences and centres have also held rounds. The public will get a chance to play later this month when the game is made available through the Program on Negotiation at Harvard Law School.

Susskind says the game shows that treaties could be improved if people discussed the issues informally much earlier on. "Too often people go into these negotiations with specific instructions on what positions to take," says Susskind, who heads the MITHarvard Public Disputes Program.

The game also shows the importance of having professional mediators to encourage the dialogue, according to Susskind. The simulation suggests that non-governmental organizations, scientists, and representatives of industry can contribute significantly to negotiations. "But the international community still hasn't figured out how to deal with these people," he claims.

The game is welcomed as a useful training device by Bill Moomaw, a veteran of international treaty deliberations on climate change and ozone depletion who teaches environmental policy at the Fletcher School of Law and Diplomacy at Tufts University, Massachusetts. "If diplomats could play this game before negotiations on organochlorines (or other chemicals) began, they'd have a better idea of how to come up with an effective treaty that doesn't throw out the good, safe chemicals with the bad," he says.

Moonaw also points out that the game has one big advantage over the real world you can make mistakes without destroying the environment, the economy, or national prestige.

Steve Nadis 